\title{
Effect of increased dietary crude protein levels on production performance, nitrogen utilisation, blood metabolites and ruminal fermentation of Holstein bulls
}

\author{
Chuanqi Xia', Muhammad Aziz Ur Rahman ${ }^{1,2}$, He Yang', Taoqi Shao ${ }^{1,3}$, Qinghua Qiu', \\ Huawei $\mathrm{Su}^{1, *}$, and Binghai $\mathrm{CaO}^{1, *}$
}

\footnotetext{
* Corresponding Authors:

Huawei Su

Tel: +86-010-62814346, Fax: +86-010-62814346, E-mail: suhuawei@cau.edu.cn

Binghai Cao

Tel: +86-010-62814346, Fax: +86-010-62814346,

E-mail: caobh@cau.edu.cn
}

${ }^{1}$ State Key Laboratory of Animal Nutrition, College of Animal Science and Technology, China Agricultural University, Beijing 100193, China

2 Institute of Animal and Dairy Sciences, University of Agriculture Faisalabad, Faisalabad 3800, Pakistan

${ }^{3}$ Department of Animal Sciences, University of Illinois at Urbana-Champaign, Urbana, IL 61801, USA

ORCID

Huawei Su

https://orcid.org/0000-0001-9934-9576

Binghai Cao

https://orcid.org/0000-0001-5084-8497

Submitted Feb 11, 2018; Revised Mar 19, 2018; Accepted May 2, 2018
Objective: This study investigated the effect of dietary crude protein $(\mathrm{CP})$ supplementation on nutrient intake, nitrogen $(\mathrm{N})$ utilisation, blood metabolites, ruminal fermentation and growth performance of young Holstein bulls.

Methods: Twenty-one young bulls weighing $277 \pm 11.2 \mathrm{~kg}$ were equally divided into three groups and were offered diets formulated with low CP (LCP; $10.21 \% \mathrm{CP}$ and $4.22 \%$ rumen degradable protein $[\mathrm{RDP}]$ ), medium $\mathrm{CP}(\mathrm{MCP} ; 12.35 \% \mathrm{CP}$ and $5.17 \% \mathrm{RDP})$ and high $\mathrm{CP}$ (HCP; $14.24 \% \mathrm{CP}$ and $6.03 \% \mathrm{RDP}$ ). Yellow corn silage was used as a unique forage source and was mixed with concentrate. This mixed feed was given ad libitum to the young bulls included in the study.

Results: Results showed that CP intake, blood urea nitrogen, $\mathrm{N}$ intake, total $\mathrm{N}$ excretion and $\mathrm{N}$ balance increased linearly with an increase in dietary $\mathrm{CP}$ level $(\mathrm{p}<0.05)$. However, no significant difference was observed in nutrient digestibility among the bulls receiving the different diets. Ruminal $\mathrm{pH}(\mathrm{p}<0.05)$ and ammonia nitrogen $\left(\mathrm{NH}_{3}-\mathrm{N}\right)$ concentration $(p<0.01)$ were significantly higher in the bulls receiving the MCP and HCP diets than in those receiving the LCP diet. The bulls receiving the HCP diet showed significantly higher ruminal bacterial protein level, propionate, acetate and total volatile fatty acid (TVFA) concentrations than bulls receiving the LCP $\operatorname{diet}(\mathrm{p}<0.05)$. Moreover, dietary CP level exerted a significant positive effect on the final body weight, average daily gain and gain-to-feed ratio of the bulls $(\mathrm{p}<0.05)$.

Conclusion: High dietary CP level is optimal for achieving maximum growth and high profitability without exerting a negative effect on the physiology of growing Holstein bulls.

Keywords: Crude Protein; Nutrient Intake; Nitrogen Utilisation; Ruminal Fermentation; Holstein Bull

\section{INTRODUCTION}

Corn straw silage is considered as a type of momentous roughage source in cattle husbandry and is widely used in China, especially in northern China, because of its accessibility and price. However, corn straw normally contains high level of fibre, but insufficient level of protein. Suharti et al [1] suggested that inadequate availability of nutrients in a high roughagecontaining diet might be the major cause of low production in cattle. Moreover, dietary crude protein $(\mathrm{CP})$ is crucial for promoting ruminal fermentation and nutrient digestibility. Protein supplementation of low-quality coarse diet may improve roughage utilisation and productive performance of cattle [2].

Previous studies have shown that inadequate rumen degradable protein (RDP) level reduces 
ammonia nitrogen $\left(\mathrm{NH}_{3}-\mathrm{N}\right)$ concentration in rumen fluid, which may decrease microbial growth, protein synthesis and fermentation [3]. Nevertheless, excessive protein fed to ruminants is degraded to $\mathrm{NH}_{3}-\mathrm{N}$. Moreover, absorption of excessive $\mathrm{NH}_{3}-\mathrm{N}$ into the blood increases urea conversion in the liver, which is eventually lost through urine [4]. However, excessive nitrogen results in economic loss, adverse environmental effects and possibly some metabolic diseases [5]. Therefore, it is important to feed appropriate CP rations to cattle because of the environmental impacts from nitrogen excretion.

Many studies have adopted dietary nutrition strategies to investigate the effect of different protein levels on nutrient intake, digestion and metabolism in cattle. Nutrient intake and apparent digestibility increase with an increase in dietary $\mathrm{CP}$ level [6]. Some literatures have shown that an increase in dietary protein level significantly increases blood urea-nitrogen (BUN) level [7], ruminal $\mathrm{NH}_{3}-\mathrm{N}$ concentration $[8,9]$ and urinary $\mathrm{N}$ excretion [10] and decreases $\mathrm{N}$ utilisation efficiency [11]. Ruminal fermentation can be improved because cattle receiving diets containing high $\mathrm{CP}$ level show significantly higher bacterial population [6], microbial protein synthesis [7] and volatile fatty acid (VFA) concentration in rumen fluid $[9,12]$ than cattle receiving diets containing low CP level. Previous studies evaluating optimal dietary $\mathrm{CP}$ levels for cattle have provided varied results $[11,13]$. However, most of these studies have focused on mature dairy cows and finishing cattle. Moreover, studies assessing the effects of dietary protein levels on young Holstein bulls (age, 9 to 12 months) are limited. Young animals aged 9 to 12 months show efficient body tissue deposition and have high nutrition requirement, particularly high protein requirement [14]. Galyean [15] suggested that dietary CP should be between $12.5 \%$ and $14.4 \%$ of dry matter (DM) basis for beef cattle. Based on NRC recommendations and Galyean [15] study, one can confuse the dietary inclusion of CP in the diet of beef cattle. We used NRC [14] recommendations level of CP (12.5\%) as reference in the diet of growing bulls and compared with Galyean [15] recommendations. Therefore, with reference diet, two additional CP levels (low and high) diets were also formulated.

In China, feeding system involving the specific utilisation of yellow-corn straw diet for rearing cattle is inferior. Therefore, the present study investigated the effect of dietary CP levels on feed intake, apparent nutrient digestibility, N metabolism, ruminal fermentation, bacterial protein and growth performance of Holstein bulls. Moreover, this study determined the optimal dietary $\mathrm{CP}$ level for improving $\mathrm{N}$ balance in young bulls without compromising nutrient digestibility and growth performance. Finally, this study provided a theoretical basis for formulating diets and optimising protein feed utilisation in Holstein bulls during the growing period.

\section{MATERIALS AND METHODS}

This study was conducted in the Zhuozhou City of Hebei Province of China (latitude: $39^{\circ} 21^{\prime} \mathrm{N}$, longitude: $115^{\circ} 44^{\prime} \mathrm{E}$ and altitude: $50 \mathrm{~m}$ ). Experimental bulls included in this study were cared for according to the practices mentioned in the Guide for the Care and Use of Animals in Agricultural Research and Teaching of the Animal Care and Use Committee, China Agricultural University (Beijing, China).

\section{Animals and feeding management}

The study included 21 Chinese Holstein bulls with an average age of nine months and average initial body weight (BW) of $277 \pm 11.2 \mathrm{~kg}$ (mean \pm standard deviation). The bulls were randomly allocated to receive the following three dietary treatments (seven animals per treatment) for an experimental period of three months: low crude protein (LCP; $10.21 \% \mathrm{CP}$ and $4.22 \% \mathrm{RDP}$ ), medium crude protein (MCP; $12.35 \% \mathrm{CP}$ and $5.17 \% \mathrm{RDP}$ ) and high crude protein (HCP; $14.24 \% \mathrm{CP}$ and $6.03 \% \mathrm{RDP}$ ) on $\mathrm{DM}$ basis were formulated referring to NRC [14] and Galyean [15] recommendations. The study was divided into two periods, namely, a 15-day adaptation period and three-month experimental period. In the present study, yellow corn silage was used as a unique forage source and was mixed with concentrate; moisture content of the diet was adjusted to approximately $55 \%$ of the DM. The mixed feedstuff was fed to the experimental young bulls ad libitum (5\% refusal was permitted). The animals were located in individual stalls and were fed twice daily at 0800 and $1800 \mathrm{~h}$. Moreover, bulls in all the experimental groups were provided water ad libitum. The ingredients and chemical composition of the experimental diets are presented in Table 1.

\section{Data collection and sampling}

The feed given and residuals were collected and recorded each day to calculate average dry matter intake (DMI). Weekly residual, yellow corn silage and concentrate were gathered from approximately $500 \mathrm{~g}$ samples and were stored at $-20^{\circ} \mathrm{C}$. The animals were individually weighed before the morning feeding at the start and end of the experiment to calculate weight gain; moreover, body size was measured simultaneously. Wither height (distance from the base of the front feet to the withers), body length (distance between the points of the rump and shoulder), heart girth (circumference of the chest), body barrel (circumference of the belly) and waist (circumference of the waist) were measured according to a procedure described in our previous study [16]. Body size increments were calculated based on differences in body size measurements of the bulls at the start and end of the experiment. Average daily gain (ADG) and gain-to-feed ratio (G:F) were calculated by dividing BW gain by the number of experimental days and total DMI, respectively. 
Table 1. Ingredients and chemical composition (\%) of the experimental diets (DM basis)

\begin{tabular}{|c|c|c|c|}
\hline \multirow{2}{*}{ Item } & \multicolumn{3}{|c|}{ Dietary treatments } \\
\hline & $\mathrm{LCP}$ & MCP & $\mathrm{HCP}$ \\
\hline \multicolumn{4}{|l|}{ Ingredients ( $\%$ of DM) } \\
\hline Yellow corn silage ${ }^{1)}$ & 45.00 & 45.00 & 45.00 \\
\hline Corn grain & 41.53 & 36.51 & 31.49 \\
\hline Soybean meal & 2.15 & 4.73 & 7.32 \\
\hline Rapeseed meal & 3.69 & 5.82 & 7.96 \\
\hline Wheat bran & 5.70 & 6.01 & 6.30 \\
\hline Calcium carbonate & 0.55 & 0.55 & 0.55 \\
\hline Dicalcium phosphate & 0.28 & 0.28 & 0.28 \\
\hline Sodium chloride & 0.55 & 0.55 & 0.55 \\
\hline Mineral-vitamin premix ${ }^{2)}$ & 0.55 & 0.55 & 0.55 \\
\hline \multicolumn{4}{|l|}{ Chemical composition ( $\%$ of DM) } \\
\hline Dry matter & 90.84 & 90.77 & 91.05 \\
\hline Organic matter & 93.31 & 93.27 & 93.30 \\
\hline Crude protein & 10.21 & 12.35 & 14.24 \\
\hline Rumen degradable protein ${ }^{3)}$ & 4.22 & 5.17 & 6.03 \\
\hline Total digestible nutrients ${ }^{3)}$ & 64.33 & 64.85 & 64.36 \\
\hline Neutral detergent fibre & 44.35 & 44.55 & 44.29 \\
\hline Acid detergent fibre & 23.01 & 23.16 & 23.80 \\
\hline Calcium & 0.50 & 0.52 & 0.51 \\
\hline Phosphorus & 0.26 & 0.27 & 0.25 \\
\hline \multicolumn{4}{|c|}{$\begin{array}{l}\text { DM, dry matter; LCP, low crude protein; MCP, medium crude protein; HCP, high } \\
\text { crude protein. } \\
\text { 1) The chemical composition of yellow corn silage (DM basis) was } 92.33 \% \text { for } \\
\text { organic matter, } 73.69 \% \text { for neutral detergent fibre, } 43.19 \% \text { for acid detergent } \\
\text { fibre and } 6.5 \% \text { for crude protein. } \\
\text { 2) Premix composition/kg: Vitamin A, 1,000,000 IU; Vitamin } D_{3}, 350,000 \mathrm{IU} \text {; Fe, } \\
4,200 \mathrm{mg} ; \mathrm{Cu}, 2,500 \mathrm{mg} ; \mathrm{Mn}, 5,700 \mathrm{mg} ; \mathrm{Zn}, 5,700 \mathrm{mg} ; \mathrm{I}, 85 \mathrm{mg} ; \mathrm{Se}, 85 \mathrm{mg} \text {; and } \\
\text { Co, } 30 \mathrm{mg} \text {. } \\
\text { 3) Rumen degradable protein and total digestible nutrients were calculated accord- } \\
\text { ing to NRC [14]. }\end{array}$} \\
\hline
\end{tabular}

Blood sampling: On the last day of each month, blood samples (approximately $10 \mathrm{~mL}$ ) were collected from the jugular vein of each bull before the morning feeding in tubes containing sodium heparin as an anticoagulant. Plasma samples were separated by centrifuging at $1,000 \times \mathrm{g}$ for $20 \mathrm{~min}$, and supernatant obtained was stored at $-20^{\circ} \mathrm{C}$ for further analysis. Glucose, total cholesterol, triglyceride, BUN and total protein concentrations were determined using applicable kits (Jiuqiang Biological Technology Co., Ltd, Beijing, China) and an automated analyser (HITACHI 7020 Automated Biochemical Analyzer; HITACHI, Tokyo, Japan).

Ruminal fluid sampling: At the end of the experiment, ruminal fluid sample was collected from each bull at 0, 2, 4, 6, 8, and $10 \mathrm{~h}$ after the morning feeding by using a flexible oral stomach tube. Ruminal samples obtained over three consecutive days (d 1st at 0800 and $1400 \mathrm{~h}, \mathrm{~d}$ 2nd at 1000 and 1600 $\mathrm{h}, \mathrm{d}$ 3rd at 1200 and $1800 \mathrm{~h}$ ) were combined to represent a single feeding phase. The samples were filtered using four layers of cheesecloth, and ruminal $\mathrm{pH}$ was measured immediately by using a $\mathrm{pH}$ meter (PHS-3C; Leici Scientific Instrument
Co., Ltd., Shanghai, China). Next, the filtrate was centrifuged at $10,000 \times \mathrm{g}$ for $15 \mathrm{~min}$. Approximately $10 \mathrm{~mL}$ supernatant was acidified using $3 \mathrm{~mL} 25 \%$ metaphosphoric acid solution and was frozen at $-20^{\circ} \mathrm{C}$ prior to further analysis. Ammonia nitrogen concentration was measured using a spectrophotometer (UV-1700; Shimazu Corp., Kyoto, Japan) according to a method described by Broderick and Kang [17]. The VFA concentration was analysed by performing gas chromatography (GC-2014; Shimazu Corp., Japan) with a capillary column (RTX-WAX, $30 \mathrm{~m} \times 0.25 \mathrm{~mm} \times 0.25 \mu \mathrm{m}$; Shimazu Corp., Japan), according to a method described by Kim et al [18]. Gas chromatography was performed using an automatic injector with a split ratio of 50:1 and a temperature of $220^{\circ} \mathrm{C}$. Injection volume was maintained at $0.4 \mu \mathrm{L}$, air flow was maintained at 450 $\mathrm{mL} / \mathrm{min}$, hydrogen flow was maintained at $40 \mathrm{~mL} / \mathrm{min}$ and nitrogen flow was maintained at $45 \mathrm{~mL} / \mathrm{min}$. The detector temperature was set at $250^{\circ} \mathrm{C}$. Individual VFAs were identified by comparing relative retention times with those of standard mixtures.

Residual rumen liquid was used for determining bacterial protein level by performing differential velocity centrifugation according to a method described by Berger et al [19]. Briefly, the rumen liquid was centrifuged at $500 \times g$ for $20 \mathrm{~min}$ to remove solid feedstuff particles and protozoa. Supernatant obtained was fixed with $0.9 \%$ sodium chloride-formalin solution (supernatant:solution ratio $=4: 3$ ), and total mixed liquid (approximately $225 \mathrm{~mL}$ ) was centrifuged at $22,000 \times g$ for 20 min. Next, sediment was dried in an oven for $3 \mathrm{~h}$ for obtaining the rumen liquid-associated bacterial protein.

Faeces and urine sampling: In the final three consecutive days of the experiment, the animals were tethered to determine the total-tract apparent digestibility of nutrients by using a total collection method. Faecal was thoroughly mixed and approximately $200 \mathrm{~g}$ sample (fresh weight) was collected. The samples ( $5 \%$ fresh weight) were then mixed with tartaric acid ( $10 \%$ solution), dried in an oven $\left(65^{\circ} \mathrm{C}\right.$ for $\left.72 \mathrm{~h}\right)$, then ground through a $1-\mathrm{mm}$ sieve and stored for chemical analysis. Digestibility was calculated using nutrient concentration in the faeces and the diet consumed. Total daily urine was collected from each bull during the final three days of the experiment by using a plastic barrel connected to a pipe and a funnelled rubber bag fixed to the hypogastrium (covering the urethral opening of the bull). The urine was acidified using $3.6 \mathrm{~mol} / \mathrm{L}$ sulfuric acid solution to maintained its $\mathrm{pH}$ at $<3.0 \mathrm{Next}$, approximately $50 \mathrm{~mL}$ acidified urine was sampled and stored at $-20^{\circ} \mathrm{C}$ for analysing $\mathrm{N}$ content. Feed $\mathrm{N}$ balance was calculated by subtracting mean $\mathrm{N}$ excretion (faecal and urinary $\mathrm{N}$ excretion) from the mean $\mathrm{N}$ intake.

\section{Chemical analysis}

Chemical analyses of the yellow corn silage, concentrate and faecal samples were performed for determining DM (method 
930.15) and crude ash (method 942.05) content, according to methods described by the Association of Official Analytical Chemistry (AOAC) [20]. Moreover, calcium (method 927.02) and phosphorus (method 965.17) concentrations in each ashed sample were determined using methods described by the AOAC [20]. Organic matter (OM) concentration was calculated as the difference between DM and crude ash concentrations. Crude protein was calculated using the formula $6.25 \times \mathrm{N}$, which was determined using Kjeldahl method (method 984.13) [20]. Acid detergent fibre (ADF) (method 973.18) [20] and neutral detergent fibre (NDF) with heat-stable a-amylase were measured in accordance with methods described by Van Soest et al [21].

\section{Statistical analysis}

Data were analysed using the PROC general linear model in SAS software (SAS Inst. Inc., Cary, NC, USA). The model used treatment (effect of diet), animals and overall error as the sources of variation. All the variables were considered to be fixed, except the animal and overall error, which were considered to be random. The following formula was used for performing data analysis:

$$
Y_{i j}=\mu+P_{i}+A_{j}+e_{i j},
$$

Where $Y_{i j}=$ each observation, $\mu$ = overall mean, $P_{i}=$ fixed effect of dietary protein level, $A_{j}=$ random effect of animal and $\mathrm{e}_{\mathrm{ij}}=$ error term.

Results for ruminal metabolism were analysed using PROC MIXED function available in the SAS software. The model used for ruminal parameters ( $\mathrm{pH}, \mathrm{NH}_{3}-\mathrm{N}$, and VFA concentrations and bacterial protein level), which included repeated measurements taken from the same animal, used treatment (effect of diets), animals, hours postfeeding (repeated measures being hours for ruminal fluid), treatment $\times$ hours postfeeding interaction and overall error as the sources of variation. All the variables were considered to be fixed, except the animal variable, which was considered to be random. Data analysis was performed using the following formula:

$$
\mathrm{Y}_{\mathrm{ijk}}=\mu+\mathrm{P}_{\mathrm{i}}+\mathrm{T}_{\mathrm{j}}+(\mathrm{P} \times \mathrm{T})_{\mathrm{ij}}+\mathrm{A}_{\mathrm{k}}+\mathrm{e}_{\mathrm{ijk}}
$$

Where $Y_{i \mathrm{ik}}=$ each observation, $\mu=$ overall mean, $\mathrm{P}_{\mathrm{i}}=$ fixed effect of dietary protein level, $T_{j}=$ fixed effect of hours postfeeding, $(\mathrm{P} \times \mathrm{T})_{\mathrm{ij}}=$ fixed effect of treatment $\times$ hours postfeeding interaction, $A_{k}=$ random effect of animal and $\mathrm{e}_{\mathrm{ijk}}=$ error term.

Effect of the diets on response variables was analysed using orthogonal contrasts (linear and quadratic). A probability value of $p<0.01$ indicated an extreme significant difference, $p<0.05$ indicated a significant difference and $\mathrm{p}<0.10$ indicated a tendency. Correlation coefficients among the variables were determined using Pearson correlation analysis, and Heatmap analysis was conducted using R V.3.2.3 software.

\section{RESULTS}

\section{Feed intake and apparent total-tract nutrient digestibility}

Effects of different dietary CP levels on feed intake and apparent total-tract nutrient digestibility are presented in Table 2. Dietary $\mathrm{CP}$ level significantly affected the $\mathrm{CP}$ intake by bulls $(\mathrm{p}<0.01)$. The bulls receiving the HCP and MCP diets showed higher CP intake than those receiving the LCP $\operatorname{diet}(0.93,0.86$, vs $0.77 \mathrm{~kg} / \mathrm{d}$, respectively). However, DM, ADF ( $\mathrm{p}=0.057)$, and NDF $(p=0.086)$ intake was similar among the bulls receiving the different diets. In addition, no significant difference was observed in the apparent total-tract digestibility of each nutrient among the bulls receiving the different diets.

\begin{tabular}{|c|c|c|c|c|c|c|}
\hline \multirow{2}{*}{ Parameters } & \multicolumn{3}{|c|}{ Dietary treatments } & \multirow{2}{*}{ SEM } & \multicolumn{2}{|c|}{$p$-value } \\
\hline & LCP & MCP & HCP & & Linear & Quadratic \\
\hline \multicolumn{7}{|l|}{ Intake } \\
\hline Dry matter $(\mathrm{kg} / \mathrm{d})$ & 7.11 & 7.39 & 7.54 & 0.205 & 0.186 & 0.856 \\
\hline Organic matter $(\mathrm{kg} / \mathrm{d})$ & 6.63 & 6.89 & 7.04 & 0.191 & 0.190 & 0.857 \\
\hline Crude protein $(\mathrm{kg} / \mathrm{d})$ & $0.77^{b}$ & $0.86^{\mathrm{a}}$ & $0.93^{\mathrm{a}}$ & 0.024 & 0.004 & 0.774 \\
\hline Neutral detergent fibre $(\mathrm{kg} / \mathrm{d})$ & 3.08 & 3.29 & 3.34 & 0.048 & 0.086 & 0.541 \\
\hline Acid detergent fibre $(\mathrm{kg} / \mathrm{d})$ & 1.64 & 1.71 & 1.79 & 0.090 & 0.057 & 0.876 \\
\hline \multicolumn{7}{|l|}{ Apparent total-tract digestibility } \\
\hline Dry matter (\%) & 46.74 & 50.25 & 51.51 & 3.652 & 0.387 & 0.834 \\
\hline Organic matter (\%) & 55.28 & 57.59 & 59.17 & 3.159 & 0.416 & 0.950 \\
\hline Crude protein (\%) & 45.50 & 47.62 & 49.71 & 2.579 & 0.293 & 0.972 \\
\hline Neutral detergent fibre (\%) & 45.14 & 47.22 & 50.12 & 3.682 & 0.377 & 0.904 \\
\hline Acid detergent fibre (\%) & 37.84 & 39.29 & 41.03 & 3.777 & 0.574 & 0.959 \\
\hline
\end{tabular}

Table 2. Feed intake and apparent total-tract nutrient digestibility of bulls fed on experimental diets with different levels of crude protein

LCP, low crude protein; MCP, medium crude protein; HCP, high crude protein; SEM, standard error of mean.

$a, b$ Within the same row with different superscripts means significant difference $(p<0.05)$. 


\section{N metabolism}

Crude protein supplementation in the diet had a positive linear effect on $\mathrm{N}$ intake, total $\mathrm{N}$ excretion and $\mathrm{N}$ balance $(\mathrm{p}<0.05)$ (Table 3). The bulls receiving the HCP and MCP diets showed higher $\mathrm{N}$ intake than those receiving the LCP $\operatorname{diet}(148.35$, 138.09 vs $123.47 \mathrm{~g} / \mathrm{d}, \mathrm{p}<0.01)$. Total $\mathrm{N}$ excretion and $\mathrm{N}$ balance were higher in the bulls receiving the HCP diet than in those receiving LCP $\operatorname{diet}(102.32$ vs $94.00 \mathrm{~g} / \mathrm{d}, \mathrm{p}<0.05 ; 46.02$ vs 29.47 $\mathrm{g} / \mathrm{d}, \mathrm{p}<0.01$, respectively). However, no difference was observed in total $\mathrm{N}$ excretion and $\mathrm{N}$ balance between the bulls receiving the $\mathrm{HCP}$ and $\mathrm{MCP}$ diets. Furthermore, dietary $\mathrm{CP}$ level had no effect on faecal $\mathrm{N}(\mathrm{p}=0.059)$ and urinary $\mathrm{N}$ excretion.

\section{Blood metabolites}

The effect of dietary protein level on blood metabolites in the young bulls is shown in Table 4. Blood urea nitrogen concentration increased linearly from 2.47 to $2.95 \mathrm{mmol} / \mathrm{L}$ with an increase in dietary CP level $(\mathrm{p}<0.05)$. However, the concentrations of other blood metabolites were not affected linearly or quadratically by the diets containing different $\mathrm{CP}$ levels.

\section{Ruminal fermentation}

Ruminal $\mathrm{pH}$ and $\mathrm{NH}_{3}-\mathrm{N}$ concentration of the bulls receiving the HCP and MCP diets were significantly higher than those of the bulls receiving the LCP diet $(6.81,6.77$ vs $6.72 \mathrm{mg} / \mathrm{dL}$, $\mathrm{p}<0.05 ; 7.29,6.43$ vs $5.00 \mathrm{mg} / \mathrm{dL}, \mathrm{p}<0.01$; Table 5 and Figure 1). Furthermore, the bulls receiving the HCP diet showed higher ruminal bacterial protein concentration than those receiving the $\mathrm{LCP} \operatorname{diet}(0.28$ vs $0.23 \mathrm{mg} / \mathrm{dL}, \mathrm{p}<0.05)$. However, no difference was observed in ruminal bacterial protein concentration between bulls receiving the MCP and LCP diets (Table 5, Figure 2). In addition, the concentrations of VFAs, namely, propionate $(\mathrm{p}<0.05)$, acetate $(\mathrm{p}<0.01)$ and total VFA $(\mathrm{p}<0.01)$ in the rumen were significantly different among the bulls receiving the different diets. Compared with the bulls receiving the LCP diet, the bulls receiving the HCP diet showed higher concentrations of acetate ( $55.58 \mathrm{vs} 49.71 \mathrm{mmol} / \mathrm{L}$ ) and propionate (12.80 vs $10.13 \mathrm{mmol} / \mathrm{L})$. Total VFA concentration in the rumen fluid increased linearly with an increase in dietary CP level $(68.42,73.29$ vs $78.65 \mathrm{mmol} / \mathrm{L}$; Table 5, Figure 3). However, ruminal acetate:propionate ratio was not significantly different among the bulls receiving the different diets.

Table 3. Nitrogen metabolism of bulls fed on experimental diets with different levels of crude protein

\begin{tabular}{|c|c|c|c|c|c|c|}
\hline Parameters & \multicolumn{3}{|c|}{ Dietary treatments } & SEM & \multicolumn{2}{|c|}{ p-value } \\
\hline \multicolumn{7}{|l|}{ Total N } \\
\hline Total N losses ( $\mathrm{g} / \mathrm{d})$ & $94.00^{b}$ & $99.22^{\mathrm{ab}}$ & $102.32^{\mathrm{a}}$ & 1.660 & 0.011 & 0.706 \\
\hline$\%$ of intake & $76.17^{a}$ & $71.88^{\mathrm{ab}}$ & $69.10^{b}$ & 1.403 & 0.011 & 0.767 \\
\hline \multicolumn{7}{|l|}{ Urinary N } \\
\hline$\%$ of total excreted & 28.48 & 27.18 & 27.41 & 2.309 & 0.747 & 0.806 \\
\hline$\%$ of intake & 21.68 & 19.51 & 18.82 & 1.295 & 0.166 & 0.697 \\
\hline \multicolumn{7}{|l|}{ Faecal N } \\
\hline Faecal N (g/d) & 67.18 & 72.21 & 74.29 & 2.187 & 0.059 & 0.654 \\
\hline$\%$ of total excreted & 71.52 & 72.82 & 72.59 & 2.309 & 0.747 & 0.806 \\
\hline
\end{tabular}

LCP, low crude protein; MCP, medium crude protein; HCP, high crude protein; SEM, standard error of mean; N, nitrogen.

1) $\mathrm{N}$ balance $=\mathrm{N}$ intake-urinary $\mathrm{N}$-faecal $\mathrm{N}$.

a,b Within the same row with different superscripts means significant difference $(p<0.05)$.

Table 4. Blood metabolites of bulls fed on experimental diets with different levels of crude protein

\begin{tabular}{|c|c|c|c|c|c|c|}
\hline \multirow{2}{*}{ Parameters } & \multicolumn{3}{|c|}{ Dietary treatments } & \multirow{2}{*}{ SEM } & \multicolumn{2}{|c|}{$p$-value } \\
\hline & $\mathrm{LCP}$ & MCP & $\mathrm{HCP}$ & & Linear & Quadratic \\
\hline Glucose (mmol/L) & 4.85 & 4.77 & 4.82 & 0.178 & 0.890 & 0.763 \\
\hline Cholesterol (mmol/L) & 3.45 & 3.87 & 3.95 & 0.248 & 0.203 & 0.641 \\
\hline Blood urea nitrogen (mmol/L) & $2.47^{\mathrm{b}}$ & $2.64^{\mathrm{ab}}$ & $2.95^{\mathrm{a}}$ & 0.139 & 0.045 & 0.717 \\
\hline Triglycerides (mmol/L) & 0.07 & 0.06 & 0.05 & 0.009 & 0.400 & 0.918 \\
\hline Total protein (g/L) & 60.48 & 52.83 & 56.58 & 3.537 & 0.440 & 0.246 \\
\hline
\end{tabular}

LCP, low crude protein; MCP, medium crude protein; HCP, high crude protein; SEM, standard error of mean.

$a, b$ Within the same row with different superscripts means significant difference $(p<0.05)$. 


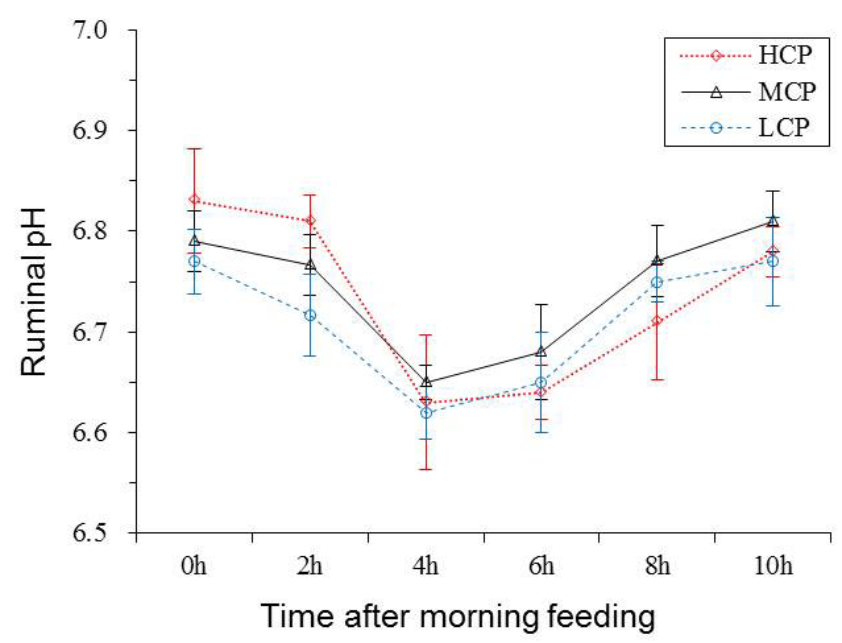

Figure 1. Ruminal $\mathrm{pH}$ value for each treatment at different sampling times after feeding. LCP, low crude protein; MCP, medium crude protein; HCP, high crude protein.

\section{Growth performance}

The growth performance of the bulls in each experimental group is presented in Table 6. Variations in the dietary protein levels significantly affected the final BW, ADG, and G:F ( $p<$ 0.05). The final BW, ADG, and G:F were significantly higher in the bulls receiving the HCP diet than in those receiving the LCP diet ( 340.0 vs $324.5 \mathrm{~kg} ; 0.68$ vs $0.55 \mathrm{~kg} / \mathrm{d} ; 0.091$ vs 0.077 , respectively, $\mathrm{p}<0.05)$. However, dietary $\mathrm{CP}$ levels did not affect the body size measurements, including body length, heart girth, body barrel and waist ( $\mathrm{p}>0.05)$, but significantly affected wither height $(p<0.05$, Table 6$)$. Furthermore, body size increments in wither height and waist of the bulls increased significantly with an increase in dietary protein levels $(\mathrm{p}<0.05)$; however, other body size increments in body length, heart girth and body barrel were not significant (Table 6).

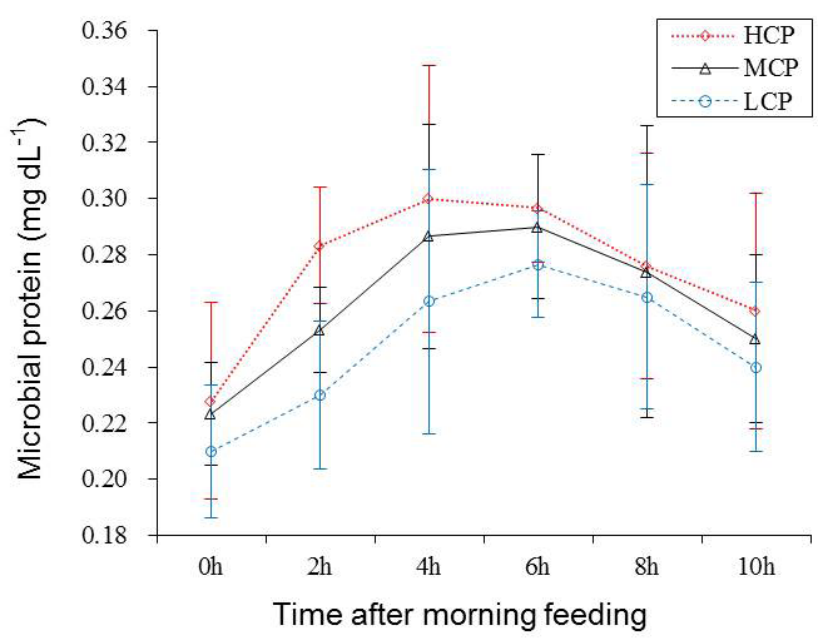

Figure 2. Ruminal bacterial protein level for each treatment at different sampling times after feeding. LCP, low crude protein; MCP, medium crude protein; HCP, high crude protein.

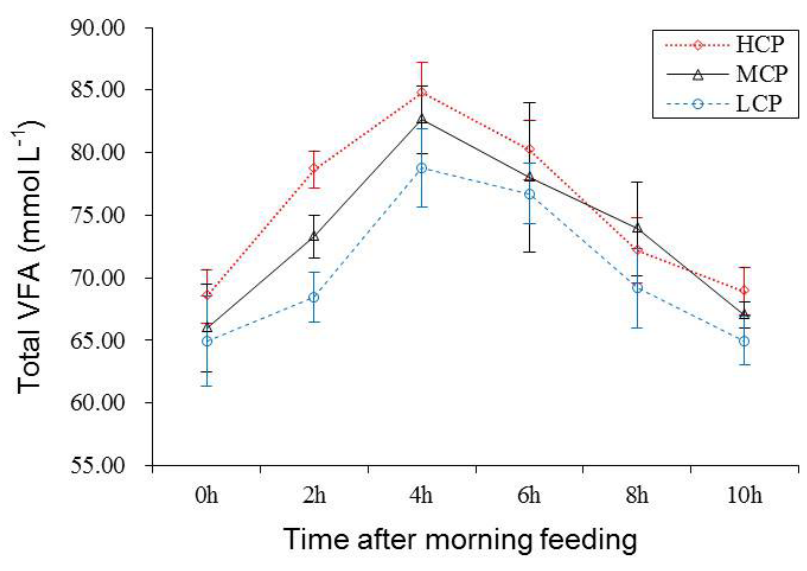

Figure 3. Ruminal total VFA concentration for each treatment at different sampling times after feeding. LCP, low crude protein; MCP, medium crude protein; HCP, high crude protein; VFA, volatile fatty acid.

Table 5. Ruminal fermentation of bulls fed on experimental diets with different levels of crude protein

\begin{tabular}{|c|c|c|c|c|c|c|}
\hline \multirow{2}{*}{ Parameters } & \multicolumn{3}{|c|}{ Dietary treatments } & \multirow{2}{*}{ SEM } & \multicolumn{2}{|c|}{$\mathrm{p}$-value } \\
\hline & LCP & MCP & HCP & & Linear & Quadratic \\
\hline Ruminal pH & $6.72^{b}$ & $6.77^{\mathrm{a}}$ & $6.81^{a}$ & 0.019 & 0.013 & 0.985 \\
\hline $\mathrm{NH}_{3}-\mathrm{N}(\mathrm{mg} / \mathrm{dL})$ & $5.00^{b}$ & $6.43^{\mathrm{a}}$ & $7.29^{\mathrm{a}}$ & 0.316 & 0.002 & 0.590 \\
\hline Bacterial protein (mg/dL) & $0.23 \mathrm{~b}$ & $0.25^{a b}$ & $0.28^{\mathrm{a}}$ & 0.012 & 0.022 & 0.752 \\
\hline \multicolumn{7}{|l|}{ Volatile fatty acids (mmo//L) } \\
\hline Acetate & $49.71^{b}$ & $52.42^{b}$ & $55.58^{\mathrm{a}}$ & 3.136 & 0.007 & 0.485 \\
\hline Propionate & $10.13^{b}$ & $11.50^{\mathrm{ab}}$ & $12.80^{\mathrm{a}}$ & 0.795 & 0.049 & 0.916 \\
\hline Iso-butyrate & 0.59 & 0.61 & 0.79 & 0.100 & 0.419 & 0.746 \\
\hline Butyrate & 6.41 & 7.19 & 7.83 & 0.516 & 0.142 & 0.459 \\
\hline Iso-valerate & 0.75 & 0.71 & 0.73 & 0.044 & 0.237 & 0.659 \\
\hline Valerate & 0.83 & 0.87 & 0.93 & 0.066 & 0.445 & 0.440 \\
\hline Total VFA (mmol/L) & $68.42^{c}$ & $73.29^{b}$ & $78.65^{\mathrm{a}}$ & 3.854 & 0.006 & 0.514 \\
\hline Acetate:propionate & 4.91 & 4.56 & 4.37 & 0.410 & 0.871 & 0.380 \\
\hline
\end{tabular}

1) LCP, low crude protein; MCP, medium crude protein; $\mathrm{HCP}$, high crude protein; $\mathrm{SEM}$, standard error of mean; $\mathrm{NH}_{3}-\mathrm{N}$, ammonia nitrogen; VFA, volatile fatty acid.

${ }^{a-c}$ Within the same row with different superscripts means significant difference $(p<0.05)$. 
Table 6. Growth performance and body size measurements of bulls fed on experimental diets with different levels of crude protein

\begin{tabular}{|c|c|c|c|c|c|c|}
\hline \multirow{2}{*}{ Parameters } & \multicolumn{3}{|c|}{ Dietary treatments } & \multirow{2}{*}{ SEM } & \multicolumn{2}{|c|}{ p-value } \\
\hline & $\mathrm{LCP}$ & MCP & HCP & & Linear & Quadratic \\
\hline \multicolumn{7}{|l|}{ Growth performance } \\
\hline Experimental days & 91 & 91 & 91 & & & \\
\hline DMI (kg/d) & 7.11 & 7.39 & 7.54 & 0.205 & 0.186 & 0.856 \\
\hline $\operatorname{ADG}(\mathrm{kg} / \mathrm{d})$ & $0.55^{b}$ & $0.61^{a b}$ & $0.68^{\mathrm{a}}$ & 0.047 & 0.041 & 0.924 \\
\hline \multicolumn{7}{|l|}{ Body size and increment } \\
\hline Wither height (cm) & $126.3^{b}$ & $127.7^{b}$ & $129.3^{\mathrm{a}}$ & 0.842 & 0.046 & 0.829 \\
\hline Increment $(\mathrm{cm})$ & $4.4 b$ & $5.1^{\mathrm{b}}$ & $6.0^{\mathrm{a}}$ & 0.448 & 0.045 & 0.665 \\
\hline Body length (cm) & 139.0 & 142.0 & 142.3 & 2.11 & 0.301 & 0.652 \\
\hline Increment (cm) & 10.0 & 10.8 & 12.3 & 0.957 & 0.149 & 0.748 \\
\hline Waist (cm) & 172.3 & 175.3 & 179.0 & 3.490 & 0.226 & 0.903 \\
\hline Increment (cm) & $7.4^{b}$ & $9.0^{\mathrm{ab}}$ & $10.8^{\mathrm{a}}$ & 0.792 & 0.024 & 0.859 \\
\hline
\end{tabular}

LCP, low crude protein; MCP, medium crude protein; HCP, high crude protein; SEM, standard error of mean; DMI, dry matter intake; ADG, average daily gain; G:F, gain-to-feed ratio.

${ }^{a, b}$ Within the same row with different superscripts means significant difference $(p<0.05)$.

\section{Correlation analysis}

The correlation coefficients of the evaluated measurements are presented in Heatmap Figure 4. Correlation analysis showed that ruminal $\mathrm{pH}$ was positively correlated with $\mathrm{CP}$ digestibility $(\mathrm{r}=0.78, \mathrm{p}<0.05)$ but was negatively correlated with $\mathrm{DM}$ digestibility $(r=-0.80, p<0.05)$ and total VFA concentration $(r$

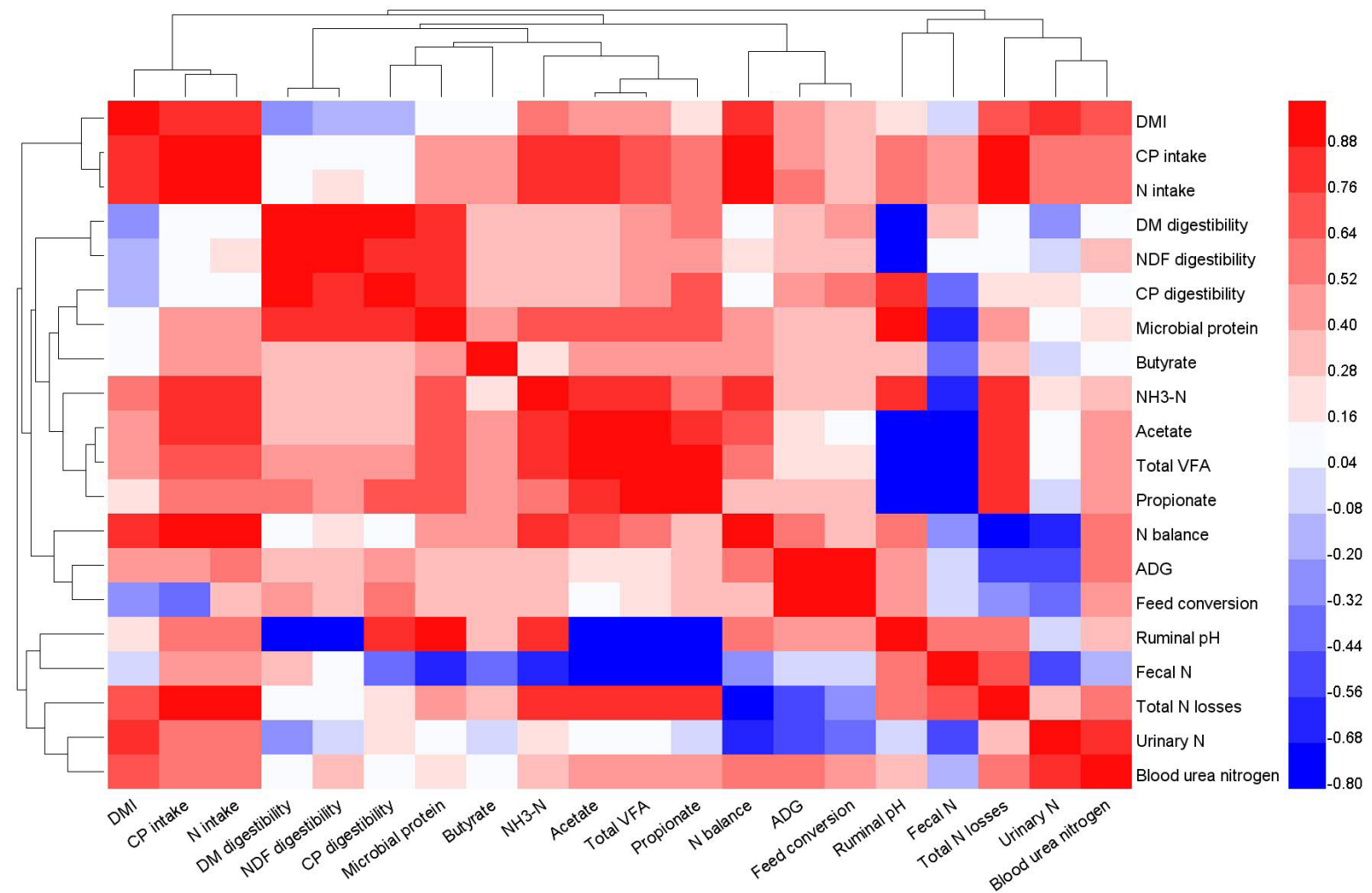

Figure 4. Heatmap matrix of the Pearson's correlation analysis showing the correlation coefficients among the evaluated measurements. $A D G$, average daily gain; $C P$, crude protein; DM, dry matter; DMI, dry matter intake; $\mathrm{N}$, nitrogen; $\mathrm{NDF}$, neutral detergent fibre; $\mathrm{NH}_{3}-\mathrm{N}$, ammonia nitrogen; VFA, volatile fatty acid. 
$=-0.76, \mathrm{p}<0.05)$. A strongly negative correlation was observed between bacterial protein level and DM digestibility $(r=0.82$, $\mathrm{p}<0.01)$ and CP digestibility $(\mathrm{r}=0.80, \mathrm{p}<0.01)$. In contrast, $\mathrm{NH}_{3}-\mathrm{N}$ and total VFA concentrations were positively correlated with $\mathrm{CP}$ intake $(\mathrm{r}=0.84, \mathrm{p}<0.01$ and $\mathrm{r}=0.74, \mathrm{p}<0.05$, respectively). With respect to $\mathrm{N}$ metabolism, a positive correlation was observed between total $\mathrm{N}$ loss and $\mathrm{CP}$ intake ( $\mathrm{r}$ $=0.90, \mathrm{p}<0.01)$ and $\mathrm{NH}_{3}-\mathrm{N}$ concentration $(\mathrm{r}=0.82, \mathrm{p}<0.01)$. Furthermore, $\mathrm{N}$ balance was positively correlated with $\mathrm{CP}$ intake $(\mathrm{r}=0.97, \mathrm{p}<0.01)$ and $\mathrm{NH}_{3}-\mathrm{N}$ concentration $(\mathrm{r}=0.79$, $\mathrm{p}<0.05)$, but was negatively correlated with total $\mathrm{N}$ loss $(\mathrm{r}=$ $-0.77, p<0.05)$. Results of other correlation analyses are shown in Figure 4.

\section{DISCUSSION}

The results of the present study indicate that $\mathrm{CP}$ intake increases linearly with an increase in dietary $\mathrm{CP}$ level, which is consistent with the result of Bahrami-Yekdangi et al [22], who also reported an improved $\mathrm{CP}$ intake in cows receiving a concentrate supplemented with increased CP levels. However, different dietary CP levels did not affect other nutrient parameters such as DM, NDF, and ADF intake. Previous studies have reported different results for the effect of different dietary $\mathrm{CP}$ levels on the apparent total-tract nutrient digestibility because of the differences in experimental conditions. In the present study, different dietary CP levels had no effect on the apparent total-tract digestibility of nutrients (Table 2). BahramiYekdangi et al [23] showed that different dietary protein levels affected the total-tract digestibility of DM, OM, ADF, and NDF. However, Dung et al [24] showed that increased CP levels $(10 \%, 13 \%, 16 \%$, and $19 \%)$ resulted in an increase in CP digestibility but did not significantly affect DM, OM, and NDF digestibility, which was inconsistent with that observed in the presentstudy. Nutrient digestibility may reflect microbial activity and fermentation in the rumen; therefore, it is crucial to formulate a proper diet to increase feed digestibility and utilisation [25]. However, the insignificant difference of nutrient digestibility among different groups might due to the lesser variation of dietary $\mathrm{CP}$ (especially RDP) in the present study. Other possible reason of non-significant difference on nutrients digestibility could be increasing tendency of NDF and ADF intake (mainly from yellow-corn straw), which reduce the digestibility improvement by higher $\mathrm{CP}$ diet.

Dietary protein is degraded into ruminal $\mathrm{NH}_{3}-\mathrm{N}$; however, excess $\mathrm{NH}_{3}-\mathrm{N}$ is converted into urinary and faecal $\mathrm{N}$ and is eventually secreted out of the body by ruminants. The present study showed a high correlation between $\mathrm{N}$ excretion and $\mathrm{CP}$ intake and between $\mathrm{NH}_{3}-\mathrm{N}$ concentration and $\mathrm{CP}$ intake $(\mathrm{r}=$ $0.90, p<0.01$ and $r=0.82, p<0.01$, respectively; Figure 4). The amount of excreted $\mathrm{N}$ reflects protein utilisation and $\mathrm{N}$ deposition efficiency. Bahrami-Yekdangi et al [23] found that faecal
$\mathrm{N}$ excretion was not affected in dairy cows fed different dietary protein levels (14.8\%, 15.6\%, and 16.4\% CP based on DM). Moreover, Reid et al [26] reported that dietary CP levels did not affect faecal and urinary $\mathrm{N}$ excreted by cows. The results of these studies are consistent with those of the present study, which is expected because $\mathrm{N}$ intake negligibly affects faecal $\mathrm{N}$ excretion. However, Davidson et al [27] reported that cows fed a low-protein (16.8\%) diet showed significantly lower urinary and faecal $\mathrm{N}$ excretion compared with those fed a highprotein (19.4\%) diet. Leonardi et al [10] also showed that increased dietary protein level increased urinary $\mathrm{N}$ excretion. However, urinary $\mathrm{N}$ excretion was not significantly different among the bulls receiving the different diets in the present study.

The highest $\mathrm{N}$ intake was observed in the bulls receiving the HCP diet. Increase in dietary CP level linearly decreased the proportion of total $\mathrm{N}$ excretion in $\mathrm{N}$ intake $(76.17 \%, 71.88 \%$, and $69.10 \%$ in the bulls receiving the LCP, MCP, and HCP diets, respectively). Furthermore, dietary $\mathrm{CP}$ level exerted a significant linear effect on $\mathrm{N}$ balance (Table 3). These results are consistent with the correlation coefficients between $\mathrm{N}$ deposition and $\mathrm{CP}$ intake $(\mathrm{r}=0.97, \mathrm{p}<0.01$; Figure 4$)$ and between $\mathrm{N}$ deposition and total $\mathrm{N}$ excretion $(\mathrm{r}=-0.77, \mathrm{p}<0.05$; Figure 4). Danes et al [11] reported that low dietary $\mathrm{CP}$ level increased $\mathrm{N}$ utilisation efficiency. In cows fed total mixed ration containing $14.8 \%, 15.6 \%$, and $16.4 \% \mathrm{CP}, \mathrm{N}$ utilisation efficiency decreased with an increase in dietary CP level [23]. Although the bulls that were fed LCP diet showed high $\mathrm{N}$ efficiency; however, the bulls in HCP diet treatment showed high N deposition in present study. Therefore, it is important to provide an appropriate dietary $\mathrm{CP}$ concentration to young bulls in the growing stage to reduce $\mathrm{N}$ excretion and to improve $\mathrm{N}$ utilisation efficiency.

In the present study, BUN concentration increased linearly with an increase in dietary CP level. Reid et al [26] reported that grass-fed dairy cows receiving supplementary concentrates with a high CP level ( $302 \mathrm{~g} / \mathrm{kg} \mathrm{DM}$ ) showed significantly higher BUN concentration than those receiving supplementary concentrates with a low CP level (101 g/kg DM); however, other blood variables such as glucose, total protein and albumin concentrations were not different among the cows receiving the different diets. Similarly, Gleghorn et al [13] and Pilachai et al [28] found that BUN concentration increased significantly in animals fed high-protein rations. These findings are consistent with those of the present study. The present study showed that the dietary $\mathrm{CP}$ level exerted a significant positive effect on ruminal $\mathrm{NH}_{3}-\mathrm{N}$ concentration, which may ultimately influence BUN concentration. Bahrami-Yekdangi et al [22] also noted that Holstein dairy cows receiving a high $\mathrm{CP}$ diet showed higher $\mathrm{CP}$ intake and BUN concentration.

Ruminal $\mathrm{pH}$ may reflect feed fermentation and internal environment in the rumen because it is influenced by nutri- 
tion levels. Increased protein content in the diet may increase $\mathrm{NH}_{3}-\mathrm{N}$ concentration in the rumen liquid, which may be the main reason for the increased ruminal $\mathrm{pH}$ value. In the present study, the results of the correlation analysis showed that ruminal $\mathrm{pH}$ was positively correlated with $\mathrm{NH}_{3}-\mathrm{N}$ concentration $(\mathrm{r}=0.80, \mathrm{p}<0.01$; Figure 4$)$, indicating that ruminal $\mathrm{pH}$ increases in animals with high $\mathrm{NH}_{3}-\mathrm{N}$ concentration. Ruminal $\mathrm{pH}$ is partly regulated by $\mathrm{NH}_{3}-\mathrm{N}$ concentration because consumed $\mathrm{CP}$ and urea are hydrolysed by microbial ureases to $\mathrm{CO}_{2}$ and $\mathrm{NH}_{3}$ in the rumen, which may lead to variations in ruminal pH [6]. However, O'Colmenero and Broderick [4] showed that ruminal $\mathrm{pH}$ was not affected by dietary protein levels, which was similar to that reported by Bahrami-Yekdangi et al [23] and Pilachai et al [28]. These differences may be because of VFA absorption rate, feedstuff formula variation and different dietary protein gradients in each experiment. High $\mathrm{NH}_{3}-\mathrm{N}$ concentration may result in the waste of $\mathrm{N}$ source, whereas low $\mathrm{NH}_{3}-\mathrm{N}$ concentration may negatively affect rumen energy and $\mathrm{N}$ balance and reduce rumen microbial activity, leading to a decrease in microbial protein synthesis [29]. The present study showed that the correlation coefficient between $\mathrm{CP}$ intake and ruminal $\mathrm{NH}_{3}-\mathrm{N}$ concentration was significantly high $(r=0.84, p<0.01$; Figure 4$)$. The results of the present study for ruminal $\mathrm{NH}_{3}-\mathrm{N}$ concentration are consistent with those of majority of previous studies. Danes et al [11] reported that dairy cows fed a high-protein (18.1\%) concentrate diet showed higher ruminal $\mathrm{NH}_{3}-\mathrm{N}$ concentration than those fed diets containing $8.7 \%$ and $13.4 \%$ CP. Javaid et al [8] reported that increased RDP level increased ruminal ammonia/ $\mathrm{NH}_{3}-\mathrm{N}$ concentration, indicating a positive correlation between ruminal $\mathrm{NH}_{3}-\mathrm{N}$ and dietary $\mathrm{RDP}$ level.

The results of the present study showed that dietary protein levels significantly affected ruminal bacterial protein level. The bulls receiving the $\mathrm{HCP}$ diet showed higher ruminal bacterial protein level than those receiving the other diets. Young bulls may more effectively utilise dietary $\mathrm{N}$ for growth. Vigorous metabolic activity in the rumen could serve as source of large amounts of $\mathrm{N}$ and energy for microbes. This was confirmed by the correlation coefficient between bacterial protein and ruminal $\mathrm{NH}_{3}-\mathrm{N}$ and VFA concentrations $(\mathrm{r}=0.76, \mathrm{p}<0.05$ and $r=0.77, p<0.05$, respectively; Figure 4). Bacterial population increases significantly with an increase in dietary protein levels [25]. Although dietary CP or RDP levels may significantly affect ruminal $\mathrm{NH}_{3}-\mathrm{N}$ concentration, they do not affect microbial protein quantity [11]. These inconsistent results of the present study might be because of the different quantity and ratio between available energy (mainly carbohydrate fermentation) and proteins used.

The VFA is the main fermentation product in the rumen, and dietary carbohydrate is the primary energy source for ruminants. The VFA concentration in the rumen is an important indicator of rumen microbial activity. Several studies have examined the effect of dietary CP levels on ruminal fermentation; however, these studies have provided inconsistent results. Pilachai et al [28] showed that VFA concentration was higher in animals fed a diet containing increased RDP level. Hatfield et al [12] reported that dietary protein level is the main factor influencing VFA concentration because acetate, propionate, butyrate, valerate, iso-butyrate, iso-valerate, and total VFA concentrations in experimental sheep fed $18 \%$ protein diet were significantly higher than those in the sheep fed $10 \%$ protein diet; however, the acetate:propionate ratio was not significantly different in the sheep fed the different diets. The results of the present study suggest that increased dietary $\mathrm{CP}$ level promotes ruminal fermentation in bulls. Moreover, some correlation was observed between ruminal total VFA concentration and $\mathrm{CP}$ intake $(\mathrm{r}=0.74, \mathrm{p}<0.05)$. However, no correlation was observed between $\mathrm{CP}$ digestibility and total VFA concentration in the rumen $(r=0.47, p=0.204$; Figure 4). Irrespective of this inscrutable result, the present study showed that high dietary CP level is beneficial for ruminal fermentation under the conditions used.

The final BW, ADG, and G:F are not affected by different dietary protein levels (12.4\% and 14.0\%) [30]. However, the results of some studies are consistent with those of the present study. Dung et al [24] found that ADG increased significantly with an increase in dietary CP level from 10\% to 19\%. Gleghorn et al [13] indicated that ADG in finishing beef steers increased slightly with an increase in dietary CP level from $11.5 \%$ to $13 \%$ and was significantly affected by a CP level exceeded $13 \%$, suggesting that suitable dietary protein level should be maintained to obtain the best growth performance. However, ADG increased linearly with the increased dietary $\mathrm{CP}$ level, and the $\mathrm{HCP}$ diet was considered to be optimal for achieving the best growth performance in young bulls in the present study. A significant difference observed in $\mathrm{CP}$ intake, ruminal fermentation parameters, $\mathrm{N}$ balance, final BW, ADG, and G:F among the bulls fed the diets containing different protein levels suggests that supplementation of diet with high CP level (14.24\% $\mathrm{CP}, 6.03 \% \mathrm{RDP}$ ) during the growing period is optimal for the growth of young Holstein bulls.

\section{CONFLICT OF INTEREST}

We certify that there is no conflict of interest with any financial organization regarding the material discussed in the manuscript.

\section{ACKNOWLEDGMENTS}

This research was supported by China Agriculture Research System (CARS-37) and Special Fund for Agro-scientific Research in the Public Interest (201303144). 


\section{REFERENCES}

1. Suharti S, Astuti DA, Wina E, Toharmat T. Rumen microbial population in the in vitro fermentation of different ratios of forage and concentrate in the presence of whole lerak (Sapindus rarak) fruit extract. Asian-Australas J Anim Sci 2011;24:108691.

2. Detmann E, Queiroz ACD, Zorzi K, et al. In vitro degradation of neutral detergent fiber of low-quality tropical forage according to supplementation with true protein and (or) non-protein nitrogen. R Bras Zootec 2011;40:1272-9.

3. Carlson DB, Litherland NB, Dann HM, Woodworth JC, Drackley JK. Metabolic effects of abomasal L-carnitine infusion and feed restriction in lactating Holstein cows. J Dairy Sci 2006;89:4819-34.

4. O'Colmenero JJ, Broderick GA. Effect of dietary crude protein concentration on milk production and nitrogen utilization in lactating dairy cows. J Dairy Sci 2006;89:1704-12.

5. Nocek JE. Bovine acidosis: implications on laminitis. J Dairy Sci 1997;80:1005-28.

6. Kang S, Wanapat M, Phesatcha K, Norrapoke T. Effect of protein level and urea in concentrate mixture on feed intake and rumen fermentation in swamp buffaloes fed rice strawbased diet. Trop Anim Health Prod 2015;47:671-9.

7. Norrapoke T, Wanapat $M$, Wanapat S. Effects of protein level and mangosteen peel pellets (Mago-pel) in concentrate diets on rumen fermentation and milk production in lactating dairy crossbreds. Asian-Australas J Anim Sci 2012;25:971-9.

8. Javaid A, Shahzad MA, Nisa M, Sarwar M. Ruminal dynamics of ad libitum feeding in buffalo bulls receiving different level of rumen degradable protein. Livest Sci 2011;135:98-102.

9. Abadi EIK, Tahmasebi AM, Mesgaran MD, Naserian AA, Vakili A. Effect of dietary crude protein level on UT-B expression and nitrogen efficiency in growing Baluchi male lambs fed low or high concentrate diets. Iran J Appl Anim Sci 2015;5: 323-32.

10.Leonardi C, Stevenson M, Armentano LE. Effect of two levels of crude protein and methionine supplementation on performance of dairy cows. J Dairy Sci 2003;86:4033-42.

11.Danes MAC, Chagas LJ, Pedroso AM, Santos FAP. Effect of protein supplementation on milk production and metabolism of dairy cows grazing tropical grass. J Dairy Sci 2013;96:40719.

12. Hatfield PG, Hopkins JA, Ramsey WS, Gilmore A. Effects of level of protein and type of molasses on digesta kinetics and blood metabolites in sheep. Small Rumin Res 1998;28:161-70.

13. Gleghorn JF, Elam NA, Galyean ML, et al. Effects of crude protein concentration and degradability on performance, carcass characteristics, and serum urea nitrogen concentrations in finishing beef steers. J Anim Sci 2004;82:2705-17.

14. NRC. Nutrient requirements of beef cattle. 7th edn. Washington DC, USA: National Academy Press; 2001.
15. Galyean ML. Protein levels in beef cattle finishing diets: Industry application, university research, and systems results. J Anim Sci 1996;74:2860-70.

16. Muhammad AUR, Xia CQ, Cao BH. Dietary forage concentration and particle size affect sorting, feeding behaviour, intake and growth of Chinese holstein male calves. J Anim Physiol Anim Nutr 2016;100:217-23.

17. Broderick GA, Kang JH. Automated simultaneous determination of ammonia and total amino acids in ruminal fluid and in vitro media. J Dairy Sci 1980;63:64-75.

18. Kim ET, Min K-S, Kim C-H, et al. The effect of plant extracts on in-vitro ruminal fermentation, methanogenesis and methanerelated microbes in the rumen. Asian-Australas J Anim Sci 2013;26:517-22.

19. Berger LL, Klopfenstein TJ, Britton RA. Effect of sodium hydroxide treatment on rate of passage and rate of ruminal fiber digestion. J Anim Sci 1980;50:745-9.

20. AOAC. Official methods of analysis of the AOAC International. 17th edn. Gaithersberg, MD, USA: AOAC International; 2000.

21.Van Soest PJ, Robertson JB, Lewis BA. Methods for dietary fiber, neutral detergent fiber, and non-starch polysaccharides in relation to animal nutrition. J Dairy Sci 1991;74:3583-97.

22. Bahrami-Yekdangi $H$, Khorvash M, Ghorbani GR, et al. Effects of decreasing metabolizable protein and rumen-undegradable protein on milk production and composition and blood metabolites of Holstein dairy cows in early lactation. J Dairy Sci 2014;97:3707-14.

23. Bahrami-Yekdangi M, Ghorbani GR, Khorvash M, Khan MA, Ghaffari MH. Reducing crude protein and rumen degradable protein with a constant concentration of rumen undegradable protein in the diet of dairy cows: Production performance, nutrient digestibility, nitrogen efficiency, and blood metabolites. J Anim Sci 2016;94:718-25.

24. Dung DV, Ba NX, Van NH, et al. Practice on improving fattening local cattle production in Vietnam by increasing crude protein level in concentrate and concentrate level. Trop Anim Health Prod 2013;45:1619-26.

25. Chanthakhoun V, Wanapat M, Berg J. Level of crude protein in concentrate supplements influenced rumen characteristics, microbial protein synthesis and digestibility in swamp buffaloes (Bubalus bubalis). Livest Sci 2012;144:197-204.

26. Reid M, O'Donovan M, Elliott CT, et al. The effect of dietary crude protein and phosphorus on grass-fed dairy cow production, nutrient status, and milk heat stability. J Dairy Sci 2015;98: 517-31.

27.Davidson S, Hopkins BA, Diaz DE, et al. Effects of amounts and degradability of dietary protein on lactation, nitrogen utilization, and excretion in early lactation Holstein cows. J Dairy Sci 2003;86:1681-9.

28. Pilachai R, Schonewille JT, Thamrongyoswittayakul C, et al. The effects of high levels of rumen degradable protein on 
rumen $\mathrm{pH}$ and histamine concentrations in dairy cows. J Anim Physiol Anim Nutr 2012;96:206-13.

29. Liu Z, Zhang CJ, Hao ZL, Li FD. Effects of total pellet feed diet with different straws on the rumen and blood metabolism parameters for sheep. China Feed 2005;11:12-4 (In Chinese).
30.Sami AS, Schuster M, Schwarz FJ. Performance, carcass characteristics and chemical composition of beef affected by lupine seed, rapeseed meal and soybean meal. J Anim Physiol Anim Nutr 2010;94:465-73. 